\title{
AKTIVITAS ANTIFIDAN EKSTRAK DAUN MINT (Mentha arvensis L.) DAN BUAH LADA HITAM (Piper nigrum L.) TERHADAP ULAT KROP KUBIS (Crocidolompa pavonana F.)
}

\author{
Amelia Hestiana ${ }^{1}$, Nur Yasin', Agus Muhammad Hariri ${ }^{1}$ \& Subeki ${ }^{2}$ \\ ${ }^{1}$ Jurusan Agroteknologi, ${ }^{2}$ Jurusan Teknologi Hasil Pertanian, Fakultas Pertanian Universitas Lampung \\ Jl. Prof. Soemantri Brodjonegoro, No. 1, Bandar Lampung 35145
}

\begin{abstract}
ABSTRAK
Salah satu hama yang banyak menimbulkan kerusakan pada tanaman kubis adalah Crocidolomia pavonana (F.). Hama ini menyerang bagian krop tanaman kubis. Salah satu alternatif pengendalian hama yang aman terhadap kesehatan manusia dan lingkungan yaitu dengan menggunakan pestisida nabati. Contohnya yang dapat dimanfaatkan sebagai pestisida nabati adalah tanaman mint (Mentha arvensis) dan buah lada hitam (Piper nigrum) diuji dalam penelitian ini melalui 3 tahapan bioassay. Pengamatan aktivitas antifidan dilakukan 24, 48, dan 72 jsa. Peubah yang diamati adalah luas daun yang dimakan larva. Hasil dari bioassay 1 ekstrak daun mint fraksi air memberikan indeks antifidan lebih tinggi $(48,74 \%)$ dibanding fraksi etil asetat $(21,61 \%)$ pada 72 jsa. Sedangkan ekstrak buah lada hitam fraksi etil asetat memiliki indeks antifidan lebih tinggi $(58,24 \%)$ dibanding fraksi air $(33,8 \%)$. Oleh karena itu fraksi air ekstrak daun mint dimasukan kedalam diaion HP 20 kolom kromatografi dan dielusi menjadi $100 \% \mathrm{H}_{2} \mathrm{O}, 20 \% \mathrm{MeOH} / \mathrm{H}_{2} \mathrm{O}, 50 \% \mathrm{MeOH} / \mathrm{H}_{2} \mathrm{O}$ dan $100 \% \mathrm{MeOH}$. Sedangkan fraksi etil asetat ekstrak buah lada hitam dimasukan kedalam di silika kolom kromatografi dan dielusi menjadi $100 \% \mathrm{CHCl}_{3}, 3 \% \mathrm{MeOH} / \mathrm{CHCl}_{3}, 20 \% \mathrm{MeOH} / \mathrm{CHCl}_{3}$, dan $100 \% \mathrm{MeOH}$. Dari keempat fraksi ini hasil bioassay 2 menunjukkan bahwa ekstrak daun mint fraksi $100 \% \mathrm{H}_{2} \mathrm{O}$ memiliki indeks antifidan lebih tinggi $\left(38,9 \%\right.$ ) dibandingkan dengan fraksi lainnya. Fraksi $100 \% \mathrm{CHCl}_{3}$ ekstrak buah lada hitam mempunyai indeks antifidan lebih tinggi (49,5\%) dibandingkan fraksi lainnya. Selanjutnya fraksi $100 \% \mathrm{H}_{2} \mathrm{O}$ dan $100 \% \mathrm{CHCl}_{3}$ diuji dengan konsentrasi 40.000 ppm, 20.000 ppm, 10.000 ppm, 5.000 ppm, 2.500 ppm, 1.250 ppm dan kontrol. Dari keenam konsentrasi ini, pada ekstrak daun mint dan buah lada hitam bioassay 3, penggunaan konsentrasi 40.000 ppm pada metode daun tanpa pilihan dan daun pilihan memberikan indeks antifidan tertinggi.
\end{abstract}

Kata kunci : insektisida nabati, ekstraksi dan fraksinasi, Mentha arvensis, Piper nigrum, Crocidolomia pavonana.

\section{PENDAHULUAN}

Hama yang banyak menimbulkan kerusakan pada tanaman kubis adalah Crocidolomia pavonana (F.). Ulat ini sering menyerang daun yang masih muda, terutama kropnya. Ulat yang masuk ke dalam krop sulit untuk dikendalikan (Sunarjono, 2010). C. pavonana menyerang tanaman kubis sejak awal pembentukan krop hingga terbentuknya krop. Sampai saat ini pengendalian C. pavonana yang dilakukan oleh petani adalah dengan menggunakan insektisida sintetik.

Aplikasi insektisida sintetik dapat dilakukan dengan mudah dan hasilnya dapat dilihat dengan cepat. Namun demikian cara ini dapat menimbulkan dampak negatif bagi organisme bukan sasaran seperti parasitoid, predator, serta resistensi dan resurgensi hama, serta pencemaran lingkungan (Perry et al, 1998 dalam Nugroho, 2008). Untuk itu, perlu dikembangkan sarana pengendalian alternatif yang efektif terhadap hama sasaran serta aman terhadap lingkungan.Saat ini telah dikembangkan insektisida nabati yang berasal dari tumbuhan untuk mengatasi dampak negatif dari penggunaan insektisida sintetik. Insektisida nabati merupakan sarana pengendalian alternatif yang lebih aman dibandingkan dengan insektisida sintetik sehingga sesuai untuk digunakan dalam pengendalian hama terpadu (PHT) (Prijono, 2006 dalam Nugroho, 2008).

Salah satu famili tumbuhan yang akhir-akhir ini sering dilakukan penelitian adalah Piperaceae. Di antara famili Piperaceae yang banyak mendapat perhatian yaitu Piper nigrum (Bernard et al, 1995; Scott et al, 2008 dalam Nugroho 2008). Ekstrak daun mint (Mentha arvensis) dapat mengendalikan hama Plutella xylostella, Spodoptera litura, dan C. pavonana (Kardinan, 2004). Namun hingga saat ini belum diketahui aktivitas antifidan ekstrak buah lada hitam dan daun mint terhadap ulat krop kubis C. pavonana. Oleh karena itu perlu dilakukan uji aktivitas antifidan ekstrak daun mint dan buah lada hitam terhadap C. pavonana. 


\section{BAHAN DAN METODE}

Penelitian ini dilaksanakan di Laboratorium Komponen Bioaktif Jurusan Teknologi Hasil Pertanian untuk ekstraksi dan fraksinasi, serta aplikasi dan pemeliharaan serangga uji. Sedangkan pemeliharaan tanaman inang dilakukan di Rumah Kaca Fakultas Pertanian, Universitas Lampung. Penelitian dilakukan pada bulan Oktober 2012 sampai Mei 2013. Tanaman inang yang digunakan untuk pemeliharaan serangga uji C. pavonana dalam pengujian ekstrak daun mint dan buah lada hitam adalah brokoli. Benih brokoli ditanam pada media semai polybag kecil berukuran $0,5 \mathrm{~kg}$. Benih yang telah ditanam pada media semai selanjutnya dipelihara pada ruangan dan disemprot air setiap hari. Setelah brokoli tumbuh setinggi $5 \mathrm{~cm}$ selanjutnya dipindahkan pada polybag yang lebih besar yang berisi tanah dan pupuk kandang seberat $5 \mathrm{~kg}$ dan pupuk NPK $0,5 \mathrm{~g}$. Tanaman brokoli dirawat di dalam rumah kaca hingga tanaman brokoli siap digunakan.

Penelitian ini diawali dengan pengumpulan larva uji dari lapangan di Way Kandis Kecamatan Tanjung Senang Bandar Lampung. Larva dikumpulkan dari bunga tanaman sawi yang terserang $C$. pavonana. Larva yang telah terkumpul dipelihara dalam stoples yang ditutup dengan kain kasa dengan pakan daun brokoli. Pada saat larva mencapai instar IV stoples diberi tanah untuk persiapan larva menjadi pupa. Ngengat yang muncul dari pupa dipelihara dalam kurungan plastik bening yang beraerasi. Di dalam kurungan diletakkan tanaman brokoli yang dapat digunakan imago sebagai media peletakan telur dan kapas yang telah diolesi madu 50\% sebagai pakan imago. Serangga uji dipelihara sampai menghasilkan telur dan dipelihara sampai diperoleh larva instar II.

Daun mint dijemur pada panas matahari, daun mint kering dan buah lada hitam kemudian dihaluskan dengan blender kering. Hasilnya ditimbang dan diperoleh sebanyak $1,4 \mathrm{~kg}$ tepung daun mint.dan $1 \mathrm{~kg}$ tepung buah lada hitam kering. Tepung daun mint kemudian direndam dalam 4,5 L sedangkan tepung buah lada direndam $2 \mathrm{~L}$ larutan alkohol $96 \%$ selama 14 hari. Setiap hari selama 10 menit dilakukan pengadukan. Filtrat disaring dengan kain saring kemudian diuapkan dengan rotary evaporator. Filtrat pekat tersebut kemudian diekstrak dengan EtOAc hingga diperoleh fraksi $\mathrm{H}_{2} \mathrm{O}$ dan EtOAc. Kedua fraksi tersebut selanjutnya dilakukan pengujian aktivitas antifidan terhadap C. pavonana pada konsentrasi 40.000 ppm sebagai bioassay 1. Hasil bioassay 1 dari kedua fraksi tersebut ternyata fraksi lapisan $\mathrm{H}_{2} \mathrm{O}$ pada ekstrak daun mint dan fraksi EtOAc terbukti mempunyai aktivitas antifidan terhadap C. pavonana. Oleh karena itu fraksi lapisan $\mathrm{H}_{2} \mathrm{O}$ pada ekstrak daun mint dan fraksi EtOAc digunakan untuk uji tahap berikutnya. Sedangkan fraksi $\mathrm{H}_{2} \mathrm{O}$ pada ekstrak daun mint selanjutnya dimasukkan ke dalam diaion HP 20 kolom kromatografi dan dielusi $100 \% \mathrm{H}_{2} \mathrm{O}(1 \mathrm{l}), 20 \% \mathrm{MeOH} / \mathrm{H}_{2} \mathrm{O}(1 \mathrm{l}), 50 \% \mathrm{MeOH} /$ $\mathrm{H}_{2} \mathrm{O}(1 \mathrm{l})$, dan $100 \% \mathrm{MeOH}(1 \mathrm{l})$. Adapun fraksi EtOAc pada ekstrak buah lada hitam dimasukkan ke dalam silika gel kolom kromatografi dan dielusi $100 \% \mathrm{CHCl}_{3}(500$ $\mathrm{ml}$, $3 \% \mathrm{MeOH} / \mathrm{CHCl}_{3}(500 \mathrm{ml}), 20 \% \mathrm{MeOH} / \mathrm{CHCl}_{3}$ $(500 \mathrm{ml})$, dan $100 \% \mathrm{MeOH}(500 \mathrm{ml})$ secara berurutan. Setiap fraksi diuapkan hingga kering dan selanjutnya dilakukan pengujian aktivitas antifidan terhadap ulat krop kubis pada konsentrasi 40.000 ppm sebagai bioassay 2. Dari masing-masing fraksi tersebut ternyata fraksi $100 \% \mathrm{H}_{2} \mathrm{O}$ pada ekstrak daun mint dan fraksi $100 \%$ $\mathrm{CHCl}_{3}$ pada ekstrak buah lada hitam terbukti mempunyai aktivitas antifidan terhadap C. pavonana. Oleh karena itu fraksi $100 \% \mathrm{H}_{2} \mathrm{O}$ dan $100 \% \mathrm{CHCl}_{3}$ diuapkan hingga kering dengan rotary evaporator untuk bioassay 3 dengan konsentrasi 40.000 ppm, 20.000 ppm, 10.000 ppm, 5.000 ppm, 2.500 ppm, 1.250 ppm, dan kontrol.

Pada pengujian ekstrak daun mint dan buah lada hitam terdapat dua uji yaitu uji potong daun tanpa pilihan dan Uji potong daun pilihan. Pada uji potong daun tanpa pilihan, potongan daun dibuat dengan cara memotong daun brokoli sehingga membentuk segi empat $(4 \times 4$ $\mathrm{cm})$. Setiap potongan daun dicelupkan pada ekstrak daun mint atau buah lada hitam selama 5 detik. Potongan daun kemudian diangkat menggunakan pinset untuk dikering-anginkan, sedangkan potongan daun kontrol dicelupkan pada aquades lalu diletakkan dalam stoples (diameter 14 dan tinggi $6 \mathrm{~cm}$ ) yang diberi kertas putih sebagai alasnya. Pada tutup stoples plastik dibuat jendela sirkulasi udara dari kain kasa (diameter $5 \mathrm{~cm}$ ) di bagian tengahnya. Daun yang tertinggal diamati kemudian diganti dengan daun yang segar (Dadang dan Prijono, 2008). 25 ekor larva C. pavonana instar II dilepas ke masing-masing stoples dan dibiarkan makan selama 24 jam. Pada uji potong daun pilihan, pengujian dengan metode pilihan dilakukan melalui prosedur yang sama dengan uji tanpa pilihan, tetapi dalam perlakuan ini potongan daun perlakuan dan kontrol diletakan dalam stoples yang sama. Tiga potongan daun perlakuan ekstrak daun mint atau buah lada hitam, dan tiga potongan daun kontrol disusun secara berurutan di sekitar pinggiran toples plastik (Dadang dan Prijono, 2008).

Pengamatan dilakukan terhadap aktivitas makan larva C. pavonana. Konsentrasi ekstrak daun mint dan buah lada hitam. Peubah yang dpamati adalah luas daun yang dimakan larva. Pengamatan aktivitas makan dilakukan setpap 24, 48, dan 72 jam setelah aplikasi. 
Untuk menghitung persentase penghambat makan pada metode tanpa pilihan, pengaruh penghambat ekstrak pada aktivitas makan larva diukur melalui indeks antifidan yang dihitung berdasarkan luas daun dimakan larva (Bentley dan Hassanali, 1987) sebagai berikut:

$$
I A=\frac{L k-L p}{L k} \times 100 \%
$$

Keterangan:

IA = Indeks Antifidan (\%)

$\mathrm{Lk}=$ luas daun kontrol yang dimakan larva

$\mathrm{Lp}=$ luas daun perlakuan yang dimakan larva

Untuk menghitung persentase penghambat makan pada metode pilihan, penghitungan indeks antifidan yang dihitung berdasarkan luas daun yang dimakan larva dilakukan dengan rumus sebagai berikut :

$$
I A=\frac{L k-L p}{L k+L p} \times 100 \%
$$

Keterangan :

$\mathrm{IA}=$ Indeks Antifidan (\%)

$\mathrm{Lk}=$ Luas daun kontrol yang dimakan larva

$\mathrm{Lp}=$ Luas daun perlakuan yang dimakan larva

\section{HASIL DAN PEMBAHASAN}

Pengamatan aktivitas antifidan ekstrak daun mint dan buah lada hitam Bioassay-1. Dari hasil pengamatan indeks antifidan ekstrak daun mint dan buah lada hitam, berdasarkan luas daun yang dimakan larva (LDML) $C$. pavonana metode tanpa pilihan. Indeks antifidan mengalami peningkatan setelah diberi pakan perlakuan ekstrak daun mint dan buah lada hitam (Tabel 1 dan 2). Dari pengamatan pada 24, 48, dan 72 jsa (jam setelah aplikasi) pada fraksi air, indeks antifidan berdasarkan LDML berturut-turut sebesar $19,48 \%, 30,87 \%$, dan $48,74 \%$. Sedangkan indeks antifidan pada fraksi etil asetat untuk 24, 48, dan 72 jsa berturut sebesar $17,36 \%$, $16,92 \%$, dan $21,61 \%$. Hasil penelitian membuktikan

Tabel 1. Indeks antifidan berdasarkan luas daun dimakan larva C. Pavonana pada metode tanpa pilihan ekstrak daun mint fraksi air dan etil asetat pada konsentrasi $40.000 \mathrm{ppm}$.

\begin{tabular}{ccc}
\hline \multirow{2}{*}{ Waktu (jsa) } & \multicolumn{2}{c}{ Indeks antifidan (\%) } \\
\cline { 2 - 3 } & Etil asetat & Air \\
\hline 24 & 17,36 & 19,48 \\
48 & 16,92 & 30,87 \\
72 & 21,61 & 48,74 \\
\hline
\end{tabular}

bahwa fraksi air memiliki aktivitas antifidan lebih tinggi dibandingkan fraksi etil asetat (Tabel 1). Hal ini terjadi kemungkinan karena kandungan senyawa bioaktif dari daun mint lebih banyak dimiliki oleh fraksi air.

Senyawa bioaktif yang terkandung yaitu senyawa etil asetate, limonene, dan neomenthol yang mempunyai aktivitas sebagai insektisida. Senyawa tersebut dapat menyebabkan penurunan aktivitas makan larva $C$. pavonana karena dapat menghambat proses sintesis protein di dalam tubuh larva. Selain senyawa tersebut, menthol merupakan kandungan utama dari ekstrak daun mint yang memberikan pengaruh antifidan terhadap larva C. pavonana (Sastrohamidjojo, 2004).

Dari pengamatan pada 24, 48, dan 72 jsa untuk fraksi air indeks antifidan berturut-turut sebesar $24,07 \%$, $19,72 \%$, dan $33,88 \%$. Sedangkan indeks antifidan pada fraksi etil asetat untuk 24, 48, dan 72 jsa berturut sebesar $27,9 \%, 47,07 \%$, dan 58,24\%. Hasil pengujian ekstrak buah lada hitam berdasarkan luas daun yang dimakan larva $C$. pavonana diketahui bahwa fraksi lapisan etil asetat ekstrak buah lada hitam memiliki indeks antifidan lebih tinggi dibandingkan fraksi air (Tabel 2). Fraksi etil asetat kemungkinan memiliki kandungan lebih banyak senyawa bioaktif yang menyebabkan aktivitas antifidan.

Senyawa bioaktif yang tekandung pada ekstrak buah lada hitam fraksi etil asetat yaitu alkaloid, methylpyrolline, piperovaline, chavicine, dan piperidine (Kardinan, 2004). Sedangkan pada fraksi air kemungkin senyawa-senyawa bioaktif yang terkandung hanya sedikit sehingga indeks antifidan yang dimiliki lebih rendah dibandingkan dari fraksi etil asetat. Hasil dari bioassay 1 dari masing-masing fraksi yang memiliki aktivitas antifidan tinggi kemudian dilanjutkan pada bioassay 2.

Pengamatan aktivitas antifidan ekstrak daun mint dan buah lada hitam pada Bioassay -2. Dari hasil penelitian bioassay-1, fraksi etil asetat dilanjutkan dengan memasukkan ekstrak ke dalam kolom khromatografi. Pada ekstrak daun mint, fraksi air dimasukan ke dalam diaion Hp 20 kolom kromatografi

Tabel 2. Indeks antifidan berdasarkan luas daun dimakan larva C. Pavonana pada metode tanpa pilihan ekstrak buah lada hitam fraksi air dan etil asetat pada konsentrasi 40.000 ppm.

\begin{tabular}{ccc}
\hline & \multicolumn{2}{c}{ Indeks antifidan $(\%)$} \\
\cline { 2 - 3 } Waktu (jsa) & Etil asetat & Air \\
\hline 24 & 27,960 & 24,07 \\
48 & 47,07 & 19,72 \\
72 & 58,24 & 33,88 \\
\hline
\end{tabular}


dan dielusi dengan $100 \% \mathrm{H}_{2} \mathrm{O}(1 \mathrm{~L}), 20 \% \mathrm{MeOH} / \mathrm{H}_{2} \mathrm{O}$ $(1 \mathrm{~L}), 50 \% \mathrm{MeOH} / \mathrm{H}_{2} \mathrm{O}(1 \mathrm{~L})$, dan $100 \% \mathrm{MeOH}(1 \mathrm{~L})$ secara berurutan. Sedangkan pada ekstrak buah lada hitam, fraksi etil asetat dimasukan ke dalam silika kolom kromatografi dan dielusi dengan $100 \% \mathrm{CHCl}_{3}(500 \mathrm{~mL})$, $3 \% \mathrm{MeOH} / \mathrm{CHCl}_{3}(500 \mathrm{~mL}), 20 \% \mathrm{MeOH} / \mathrm{CHCl}_{3}(500$ $\mathrm{mL})$, dan $100 \% \mathrm{MeOH}(500 \mathrm{~mL})$ secara berurutan.

Hasil penelitian aktivitas antifidan ekstrak daun mint, perlakuan fraksi $100 \% \mathrm{H}_{2} \mathrm{O}$ menunjukkan indeks antifidan lebih tinggi dibandingkan dengan fraksi lainnya. Dari pengamatan 24, 48, dan 72 jsa, indeks antifidannya makin meningkat dan semakin tinggi kandungan $\mathrm{MeOH}$ indeks antifidannya makin kecil (Tabel 3).

Dari pengujian ekstrak buah lada hitam diketahui bahwa fraksi $100 \% \mathrm{CHCl}_{3}$ ekstrak buah lada hitam memiliki aktivitas antifidan lebih tinggi dibandingkan fraksi lainnya. Pengamatan 24, 48, dan 72 jsa indeks antifidannya makin meningkat. Sedangkan semakin tinggi kandungan $\mathrm{MeOH}$ indeks antifidannya makin kecil (Tabel 4). Hal ini karena kemungkinan fraksi 100\% $\mathrm{CHCl}_{3}$ memiliki kandungan ekstrak lebih murni dibandingkan dengan fraksi lainnya.

Pascaaplikasi pengujian ekstrak daun mint dan buah lada hitam berdasarkan berdasarkan luas daun yang dimakan larva $C$. pavonana metode tanpa pilihan, diketahui bahwa fraksi $100 \% \mathrm{H}_{2} \mathrm{O}$ ekstrak daun mint dan fraksi $100 \% \mathrm{CHCl}_{3}$ memiliki aktivitas antifidan paling tinggi dibandingkan fraksi lainnya. Hal ini kemungkinan karena fraksi $100 \% \mathrm{H}_{2} \mathrm{O}$ dan $100 \% \mathrm{CHCl}_{3}$ dari masingmasing ekstrak lebih murni dibandingkan dengan fraksi lainnya. Fraksi $100 \% \mathrm{H}_{2} \mathrm{O}$ dan $100 \% \mathrm{CHCl}_{3}$ didapatkan pada saat pengelmusian pertama yang kemungkinan menyebabkan fraksi tersebut memiliki lebih banyak kandungan senyawa bioaktif yang terkandung dalam daun mint, sehingga menyebabkan aktivitas antifidan yang lebih tinggi dibandingkan fraksi lainnya. Sedangkan pada fraksi $20 \% \mathrm{MeOH} / \mathrm{H}_{2} \mathrm{O}, 50 \% \mathrm{MeOH} /$ $\mathrm{H}_{2} \mathrm{O}$, dan $100 \% \mathrm{MeOH}$ dari ekstrak daun mint dan fraksi $3 \% \mathrm{MeOH} / \mathrm{CHCl}_{3}, 20 \% \mathrm{MeOH} / \mathrm{CHCl}_{3}$, dan $100 \%$ $\mathrm{MeOH}$ dari ekstrak buah lada hitam didapat dari pengelmusian berikutnya setelah fraksi $100 \% \mathrm{H}_{2} \mathrm{O}$ dan $100 \% \mathrm{CHCl}_{3}$ sehingga kemungkin senyawa-senyawa bioaktif yang terkandung dalam ekstrak daun mint yang dimiliki hanya sedikit, sehingga indeks antifidan yang dimiliki lebih rendah.

Pengamatan aktivitas antifidan ekstrak daun mint dan buah lada hitam pada Bioassay -3. Dari hasil bioassay-2, fraksi $100 \% \mathrm{H}_{2} \mathrm{O}$ dari ekstrak daun mint dan fraksi $100 \% \mathrm{CHCl}_{3}$ dari ekstrak buah lada, kemudian masing-masing dibuat konsentrasi 40.000 ppm, 20.000 ppm, 10.000 ppm, 5.000 ppm, 2.500 ppm, 1.250 ppm dan kontrol. Pengamatan aktivitas antifidan ekstrak daun mint dan buah lada hitam pada metode daun tanpa pilihan. Konsentrasi 40.000 ppm ekstrak daun mint menunjukkan indeks antifidan lebih tinggi dibandingkan dengan penggunaan konsentrasi lainnya. Dari pengamatan 24, 48, dan 72 jsa diketahui indeks antifidannya makin meningkat, serta makin tinggi konsentrasi ekstrak daun mint semakin tinggi indeks antifidannya (Tabel 5).

Konsentrasi 40.000 ppm ekstrak buah lada hitam menunjukkan indeks antifidan lebih tinggi dibandingkan dengan penggunaan konsentrasi lainnya. Dari pengamatan 24, 48, dan 72 jsa diketahui indeks antifidannya makin meningkat, serta makin tinggi konsentrasi ekstrak buah lada hitam semakin tinggi indeks antifidannya (Tabel 6). Pengamatan aktivitas

Tabel 3. Indeks antifidan berdasarkan luas daun dimakan larva $C$. pavonana pada metode tanpa pilihan pada berbagai fraksi daun mint dengan konsentrasi 40.000 ppm.

\begin{tabular}{ccccc}
\hline \multirow{2}{*}{ Waktu (jsa) } & \multicolumn{4}{c}{ Indeks antifidan (\%) } \\
\cline { 2 - 5 } & $100 \% \mathrm{MeOH}$ & $50 \% \mathrm{MeOH} / \mathrm{H}_{2} \mathrm{O}$ & $20 \% \mathrm{MeOH} / \mathrm{H}_{2} \mathrm{O}$ & $100 \% \mathrm{H}_{2} \mathrm{O}$ \\
\hline 24 & 3,63 & 5,86 & 10,71 & 15,30 \\
48 & 6,80 & 9,16 & 11,96 & 34,86 \\
72 & 9,31 & 10,65 & 12,11 & 38,95 \\
\hline
\end{tabular}

Tabel 4. Indeks antifidan berdasarkan luas daun dimakan larva $C$. pavonana pada metode tanpa pilihan pada berbagai fraksi ekstrak buah lada hitam dengan konsentrasi 40.000 ppm.

\begin{tabular}{ccccc}
\hline \multirow{2}{*}{ Waktu (jsa) } & \multicolumn{4}{c}{ Indeks antifidan (\%) } \\
\cline { 2 - 5 } & $100 \% \mathrm{MeOH}$ & $20 \% \mathrm{MeOH} / \mathrm{CHCl}_{3}$ & $3 \% \mathrm{MeOH} / \mathrm{CHCl}_{3}$ & $100 \% \mathrm{CHCl}_{3}$ \\
\hline 24 & 14,98 & 16,16 & 20,75 & 25,27 \\
48 & 18,47 & 17,06 & 19,46 & 42,97 \\
72 & 21,24 & 21,15 & 21,17 & 49,56 \\
\hline
\end{tabular}


antifidan ekstrak daun mint dan buah lada hitam pada metode daun pilihan. Konsentrasi 40.000 ppm ekstrak daun mint menunjukkan indeks antifidan lebih tinggi dibandingkan dengan penggunaan konsentrasi lainnya. Dari pengamatan 24, 48, dan 72 jsa diketahui indeks antifidannya makin meningkat, serta makin tinggi konsentrasi ekstrak daun mint semakin besar indeks antifidannya (Tabel 7). Konsentrasi 40.000 ppm ekstrak buah lada hitam menunjukkan indeks antifidan lebih tinggi dibandingkan dengan penggunaan konsentrasi lainnya. Dari pengamatan 24, 48, dan 72 jsa diketahui indeks antifidannya makin meningkat, serta makin tinggi konsentrasi ekstrak buah lada hitam semakin tinggi indeks antifidannya (Tabel 8).

Tabel 5. Indeks antifidan berdasarkan luas daun dimakan larva $C$. pavonana pada metode tanpa pilihan pada berbagai konsentrasi fraksi $100 \% \mathrm{H}_{2} \mathrm{O}$ ekstrak daun mint.

\begin{tabular}{ccccccc}
\hline \multirow{2}{*}{ Waktu (jsa) } & \multicolumn{5}{c}{ Indeks antifidan $(\%)$} \\
\cline { 2 - 7 } & $40.000 \mathrm{ppm}$ & $20.000 \mathrm{ppm}$ & $10.000 \mathrm{ppm}$ & $5.000 \mathrm{ppm}$ & $2.500 \mathrm{ppm}$ & $1.250 \mathrm{ppm}$ \\
\hline 24 & 21,77 & 15,85 & 12,66 & 9,68 & 6,58 & 5,14 \\
48 & 33,16 & 24,22 & 20,09 & 16,39 & 10,95 & 7,70 \\
72 & 42,14 & 29,57 & 22,24 & 20,27 & 17,03 & 9,29 \\
\hline
\end{tabular}

Tabel 6. Indeks antifidan berdasarkan luas daun dimakan larva C. pavonana pada metode tanpa pilihan fraksi $100 \% \mathrm{CHCl}_{3}$ ekstrak buah lada hitam.

\begin{tabular}{ccccccc}
\hline \multirow{2}{*}{ Waktu (jsa) } & \multicolumn{5}{c}{ Indeks antifidan (\%) } \\
\cline { 2 - 6 } & $40.000 \mathrm{ppm}$ & $20.000 \mathrm{ppm}$ & $10.000 \mathrm{ppm}$ & $5.000 \mathrm{ppm}$ & $2.500 \mathrm{ppm}$ & $1.250 \mathrm{ppm}$ \\
\hline 24 & 31,07 & 26,07 & 23,10 & 19,28 & 14,86 & 12,29 \\
48 & 48,16 & 34,36 & 30,57 & 27,61 & 21,54 & 16,73 \\
72 & 54,17 & 37,98 & 35,21 & 31,07 & 26,44 & 20,18 \\
\hline
\end{tabular}

Tabel 7. Indeks antifidan berdasarkan luas daun dimakan larva C. pavonana pada metode pilihan fraksi $100 \%$ $\mathrm{H}_{2} \mathrm{O}$ ekstrak daun mint.

\begin{tabular}{ccccccc}
\hline \multirow{2}{*}{ Waktu (jsa) } & \multicolumn{5}{c}{ Indeks antifidan (\%) } \\
\cline { 2 - 7 } & $40.000 \mathrm{ppm}$ & $20.000 \mathrm{ppm}$ & $10.000 \mathrm{ppm}$ & $5.000 \mathrm{ppm}$ & $2.500 \mathrm{ppm}$ & $1.250 \mathrm{ppm}$ \\
\hline 24 & 34,81 & 22,77 & 20,06 & 17,74 & 12,30 & 10,51 \\
48 & 42,58 & 28,12 & 26,13 & 22,40 & 18,16 & 15,59 \\
72 & 51,29 & 38,27 & 32,81 & 27,67 & 25,18 & 21,25 \\
\hline
\end{tabular}

Tabel 8. Persentase aktivitas antifidan berdasarkan luas daun dimakan larva $C$. pavonana pada metode pilihan fraksi $100 \% \mathrm{CHCl}_{3}$ ekstrak buah lada hitam.

\begin{tabular}{ccccccc}
\hline \multirow{2}{*}{ Waktu (jsa) } & \multicolumn{5}{c}{ Indeks antifidan $(\%)$} \\
\cline { 2 - 6 } & $40.000 \mathrm{ppm}$ & $20.000 \mathrm{ppm}$ & $10.000 \mathrm{ppm}$ & $5.000 \mathrm{ppm}$ & $2.500 \mathrm{ppm}$ & $1.250 \mathrm{ppm}$ \\
\hline 24 & 39,21 & 32,17 & 29,26 & 25,95 & 22,25 & 18,43 \\
48 & 48,35 & 40,42 & 33,72 & 29,06 & 28,00 & 26,32 \\
72 & 64,15 & 51,99 & 44,21 & 35,37 & 30,60 & 27,44 \\
\hline
\end{tabular}




\section{KESIMPULAN}

Penggunaan ekstrak daun mint (Mentha arvensis L.) dan buah lada hitam (Piper nigrum L.) memiliki aktivitas antiifidan terhadap larva Crocidolomia pavonana $\mathrm{F}$. Penggunaan ekstrak daun mint fraksi air dan fraksi etil asetat buah lada hitam memiliki indeks antifidan masing-masing sebesar $48,74 \%$ dan $58,24 \%$ pada 72 jsa dengan konsentrasi $40.000 \mathrm{ppm}$. Pada fraksi $100 \% \mathrm{H}_{2} \mathrm{O}$ ekstrak daun mint dan fraksi $100 \% \mathrm{CHCl}_{3}$ memiliki indeks antifidan masing-masing sebesar $38,95 \%$ dan 49,56\% pada 72 jsa dengan konsentrasi 40.000 ppm. Pengujian ekstrak daun mint dan buah lada hitam pada 72 jsa konsentrasi 40.000 ppm memiliki indeks antifidan paling tinggi dibandingkan dengan konsentrasi lainnya yang lebih rendah, yaitu masing-masing sebesar $42,14 \%$ dan $54,17 \%$ pada metode uji potong daun tanpa pilihan.

\section{DAFTAR PUSTAKA}

Dadang dan Prijono, D. 2008. Insektisida Nabati; Prinsip, Pemanfaatan, dan Pengembangan. IPB, Bogor.

Hassanali, A. dan M. D. Bentley. 1987. Comparison of the insect antifeedant activities of some limonoids. Pp 683-689 In : Natural Pesticides from the Neem Tree an other tropical plant. Srcumutterer, H. and K. R. S. Ascher. (Eds). Procceding of the Therd International Neem Conference. Kenya. 730 hlm.
Kardinan, A. 2004. Pestisida Nabati Ramuan dan Aplikasi. http://one.indoskripsi.com/node/ 3090. Diakses pada tanggal 13 Oktober 2012.

Nugroho, D. A. 2008. Aktivitas residu ekstrak buah Piper cubeba (Piperaceae) dan daun Tephrosia vogelii Hook. F. (Leguminosae) terhadap larva Crocidolomia pavonana (F.) (Lepidoptera: Crambidae). Skripsi. Departemen Proteksi Tanaman, Fakultas Pertanian, IPB. Bogor. $61 \mathrm{hlm}$.

Santoso, S. J. dan Sumarmi. 2008. Pengendalian Plutella xylostella dan Crocidolomia pavonana pada tanaman kubis dengan insektisida hayati. Bandung. Eksplorasi. Vol. XX No 1 Tahun 2008. $85 \mathrm{hlm}$.

Sastrohamidjojo, H. 2004. Kimia Minyak Atsiri. Universitas Gadjah Mada. Yogyakarta. $185 \mathrm{hlm}$.

Suhirman dan Ma'mun. 2010. Karakteristik minyak atsiri potensial. Balai Penelitian Tanaman Obat dan Aromatik. Bogor. 120 hlm.

Sunarjono, H. 2010. Bertanam 30 Jenis Sayur. Jakarta. Penebar Swadaya. $79 \mathrm{hlm}$. 